\title{
POGIL model on mathematical connection ability viewed from self-regulated learning
}

\author{
Enyta Ramadisae Putri $^{1}$, Budiyono ${ }^{2}$, Diari Indriati ${ }^{3}$ \\ 1,2Department of Mathematics Education, Sebelas Maret University, Indonesia \\ ${ }^{3}$ Department of Mathematics, Sebelas Maret University, Indonesia
}

\begin{abstract}
Article Info
Article history:

Received Sep 9, 2019

Revised Mar 15, 2020

Accepted May 1, 2020

Keywords:

Connection ability

Mathematic

POGIL model

Self-regulated learning

ABSTRACT

One area of education which has not escaped efforts to improve the Indonesian government is mathematics education. The Indonesian government must make good use of mathematics learning so that students can use the mathematical mindset to offset the pace of global competition This research is an experimental research on the Process-Oriented Guided Inquiry Learning (POGIL) model on the ability of mathematical connections in terms of self-regulated learning. The design used in this study was a $2 \times 3$ factorial. The research sample was 179 students from $7^{\text {th }}$ grade in three State Junior High Schools in Sukoharjo Regency, Central Java, Indonesia. The research sample consisted of an experimental group that subjected to the POGIL model and a control group that subjected to a direct learning model. This research instrument used was a written test and questionnaire. The data analysis technique used was a two-way ANOVA test with unbalanced cells and post hoc test. The results showed that: 1) the POGIL model produces better mathematical connection ability than the direct learning model, 2) Students with high category self-regulated learning have better mathematical connection ability than medium and low categories, and students with self-regulated learning the medium category have better mathematical connection ability than the low category.
\end{abstract}

This is an open access article under the CC BY-SA license.

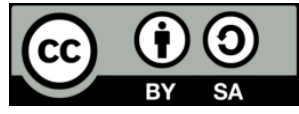

Corresponding Author:

Enyta Ramadisae Putri,

Department of Mathematics Education,

Sebelas Maret University,

Surakarta, Center Java, Indonesia.

Email: enytaramadisaeputri@gmail.com

\section{INTRODUCTION}

The primary key of a country is education. Education often likened to a symbol of the strength, dignity, and greatness of a nation. Nowadays, education plays an essential role in creating generations of nations that can keep pace with the pace of development of science and technology. Education is required to form a generation that can act effectively in the face of rapid and complex world changes [1]. One area of education which has not escaped efforts to improve the Indonesian government is mathematics education. The Outlines of the Teaching Program provides general objectives of learning mathematics [2], namely preparing students to be able to deal with changing circumstances and the world that is always developing, through the practice of acting on the basis of logical, rational, critical thinking, careful, honest, effective and efficient. Then, prepare students to be able to use mathematics and mathematical thinking patterns in everyday life and in learning various sciences. Also, the mathematical vision developed by NCTM is that those with excellent mathematical competence significantly open the door to a productive future because mathematics is the key to opportunities in this changing world [3]. In most Asian countries, 
the practice of guiding children's mathematics is quite more vigorous [4]. As shown by Guinocor [5], which shows the changes in cognitive, skills, and attitudes of each student in learning. So, for a successful student studying mathematics will have the opportunity to compete in the face of changes in the world and keep pace with the pace of development in the future. One area of Indonesia that needs attention is Sukoharjo Regency, Central Java, Indonesia. This data can be seen from the average results of the National Examination in mathematics in 41 State Junior High Schools in Sukoharjo Regency for the past two years shown in Table 1.

Table 1. Average national mathematics exam scores

\begin{tabular}{ccc}
\hline School year & Average & Category \\
\hline $2016 / 2017$ & 54.0 & C \\
$2017 / 2018$ & 53.3 & C \\
\hline
\end{tabular}

Table 1 shows that the average mathematics in the National Examination for the 2017/2018 school year decreased compared to the average 2016/2017 school year. One of the problems is the geometry and measurement material obtained by the average absorption of students by 50.65 . Mainly related to the material of the rectangle and triangle that tested consisted of the first indicator concerning determining the circumference of the two flat structures which coincided with one side and their size were known, while the second indicator concerning determining the area of cardboard was used to make capital letters. The percentage of students correct from the first indicator is $49.81 \%$, and the second indicator is $50.56 \%$. So, the percentage of the two indicators indirectly indicates that students' mathematics is low.

Mathematical connection ability is one of the essential abilities that must be possessed and developed in high school students. The term mathematical connection implies the same characteristic of the opinions of experts, namely the existence of links between ideas, concepts, principles, processes, mathematical content and theorems, and the relationship of mathematical content with the content of other fields of study or everyday problems [6]. From the standard of teaching, mathematics can summarize the ability of mathematical connections in three major components [3], namely (a) recognizing and using the relationships between ideas in mathematics, (b) understanding how the relationship of mathematical ideas and forming new mathematical ideas to produce a comprehensive relationship, and (c) recognizing and applying one mathematical content to other mathematical content and environments outside mathematics. In more detail, the ability of mathematical connections can be categorized in 4 aspects [7], namely (a) connections between mathematical topics that link between concepts or principles in the same topic, (b) connections between mathematical topics that link material between specific topics with the material in other topics, (c) the connection between material and science other than mathematics, and (d) the connection with daily life.

Based on preliminary data conducted on September 27-29, 2018, students in Mojolaban 1 State Junior High School (high school category), Bulu 1 State Junior High School (medium school category), and Grogol 3 State Junior High School (low school category) given a mathematics test containing connections mathematics. The tests were mathematical connections between same topics, mathematical connections between specific topics with other topics, mathematical connections with science other than mathematics, mathematical connections with disciplines other than mathematics, and mathematical connections with everyday life. Students who were given the test almost all did not answer correctly. In addition, the results of observations and interviews conducted with mathematics teachers show that: (a) students are less able to use mathematical concepts and procedures due to lack of understanding of preliminary knowledge or prerequisites of the material taught previously, (b) students are less able to apply mathematical concepts outside the topic of mathematics because they accustomed to being given different problems from what the teacher exemplifies but are still in the same concept, and (c) the teacher still applies direct learning, meaning teacher-centered learning, the teacher records information on the board or explains it in front of the class, while students copy in their notebooks or listen to what the teacher says. Therefore, the mathematical connection ability of State Junior High School students in Sukoharjo Regency is indicated to be relatively low.

One learning model that is expected to be able to improve mathematical connection ability is the POGIL learning model. The POGIL learning model combines the methods of guided inquiry and cooperative learning [8]. The mechanism of the POGIL learning model comes from the combination of the methodology of PO (Process Oriented) and GI (Guided Inquiry) [9]. The GI section is achieved through the use of carefully designed learning cycle activities to guide students towards the construction of their understanding. The experience of discovery can increase the confidence of students to understand and remember more. The PO part comes from the use of small groups. The positive dependency that results in 
small group settings has been shown to weaken feelings of isolation and competition, which often correlate with achievement or failure in traditional classroom environments.

The POGIL learning model is a learning model that can provide opportunities for students to interact, appreciate, and build their knowledge. Self-construction can make the process of storing students' memory knowledge longer and develop their thinking skills [10]. In its implementation, the POGIL learning model based on five key ideas about learning obtained from research results in cognitive science [11]. In the study it was concluded that students would learn by (a) building their understanding based on previous knowledge, experience, skills, attitudes, and beliefs, (b) following a learning cycle that included exploration of concept formation and application, (c) connecting and describing concepts, (d) discuss and interact with others, and (e) reflect the development and evaluation of actions. POGIL learning model design [12, 13], namely the learning cycle that builds their understanding consisting of orientation, exploration, concept formation, application, and closure. Also, so that students have sufficient skills, each member of the group has their respective roles. The assignment of roles will be different at each meeting; it intended that they contribute to each other to solve problems and have individual responsibilities. The role of students in the class can be as a manager, recorder, presenter, and reflector.

Students cannot rely solely on classroom learning which is only four hours of study per week. The success of learning must have a student's self-awareness to learn independently in addition to learning in class. Another factor needed in the success of a learning process is self-regulated learning. Yang in [6] reported that students who have high self-regulated learning: (a) tend to learn better in their supervision than in program supervision, (b) able to monitor, evaluate and manage their learning effectively, (c) save time in completing their work, and (d) managing learning and time efficiently.

Self-regulated learning consists of 4 categories [14], namely cognitive, metacognitive, selfmanagement, and motivation. Cognitive strategies are associated with cognitive behaviors and processes used by students during their learning to complete assignments or achieve academic goals. Metacognitive strategies involve prediction, planning, monitoring and evaluation that help individuals control and manage their cognitive processes. Self-management strategies embody strategies such as controlling and managing the time and environment of learning, effort, cooperation and seeking help. Motivational strategies including intrinsic values, self-efficacy, and anxiety in the test stand as the last dimension of self-regulated learning. The structure of the process of self-regulation learning consists of three main processes [15], namely forethought (the process of designing learning), performance control (the process of monitoring learning progress while implementing a design) and self-reflection (the process of evaluating learning outcomes in full). So, self-regulated learning is the awareness of individuals who actively design goals, choose strategies and monitor themselves in the learning process for achieving academic goals.

Based on the description above, the application of the POGIL learning model can provide an opportunity for students to be independent in learning without depending much on the teacher's explanation so that it will have a better impact on the ability of students' mathematical connections.

\section{RESEARCH METHOD}

The first independent variable is the model of process-oriented guided inquiry learning (POGIL) that applied to the experimental class and direct learning (DL) that applied to the control class. The second independent variable is self-regulated learning which consists of three categories, namely high, medium, and low. The dependent variable is the mathematical connection ability. This type of research is a quasiexperimental study with a $2 \times 3$ factorial design seen in Table 2 .

Table 2. Research design

\begin{tabular}{cccc}
\hline \multicolumn{4}{c}{ Self-Regulated Learning $(\mathrm{B})$} \\
Model $(\mathrm{A})$ & High $\left(\mathrm{B}_{1}\right)$ & Medium $\left(\mathrm{B}_{2}\right)$ & Low $\left(\mathrm{B}_{3}\right)$ \\
\hline POGIL $\left(\mathrm{A}_{1}\right)$ & $\mathrm{A}_{1} \mathrm{~B}_{1}$ & $\mathrm{~A}_{1} \mathrm{~B}_{2}$ & $\mathrm{~A}_{1} \mathrm{~B}_{3}$ \\
DL $\left(\mathrm{A}_{2}\right)$ & $\mathrm{A}_{2} \mathrm{~B}_{1}$ & $\mathrm{~A}_{2} \mathrm{~B}_{2}$ & $\mathrm{~A}_{2} \mathrm{~B}_{3}$ \\
\hline
\end{tabular}

The population of this research were all students $7^{\text {th }}$ grade of State Junior High Schools in Sukoharjo Regency, Central Java, Indonesia, in the academic year 2018/2019. The research sample obtained by taking students from three classes in each of the three State Junior High Schools in Sukoharjo Regency. The research sample consisted of two groups, namely the experimental group and the control group. An experimental group is a group that is subject to the POGIL learning model. A control group is a group that is subject to direct learning (DL) models. 
The sampling technique uses a stratified cluster random sampling technique. All State Junior High Schools in Sukoharjo Regency divided into high, medium and low school groups, then choose one school randomly from each school group, namely Gatak 1 State Junior High School (high school category), Kartasura 2 State Junior High School (medium school category), and Baki 2 State Junior High School (low school category). So, the sample in the study was 179 students from $7^{\text {th }}$ grade in three State Junior High Schools in Sukoharjo Regency.

Research data collection uses the written test method and questionnaire. The written test method is used to obtain mathematical connection capabilities. The questionnaire method is used to determine the level of self-regulated learning, namely the high, medium, and low categories. The written tests consists of 4 essay questions, and a questionnaire consists of 21 statements. Before using the research instrument test and questionnaire, testing is done first to find out whether the instruments that have made have met the requirements of a good instrument. Each instrument is validated by an expert validator. After that, the instrument tested outside of the research sample of 92 students. Data analysis techniques in the study uses analysis two-way ANOVA test with unbalanced cells and the post hoc test of Scheffe's method.

\section{RESULTS AND DISCUSSION}

\subsection{Analysis requirements for two-way ANOVA test with unbalanced cells}

Requirements that must be met by two-way variance analysis with unbalanced cells were each sample is taken randomly from its population, each population is mutually independent within its group, each population normally distributed, and populations have the same variance. The normality test uses the Lilliefors method taken $\alpha=0.05$ and homogeneity test uses the Barlett test taken $\alpha=0.05$. The normality test conducted five times, and the variance homogeneity test was carried out twice, which shown in Table 3 and Table 4. Table 3 shows Ho is not rejected because $\mathrm{L}_{\text {observation }}$ was less than $\mathrm{L}_{\text {table, }}$, so the conclusion is that each sample comes from a normally distributed population. Afterward, Table 4 shows Ho is not rejected because $\chi^{2}{ }_{\text {observation }}$ is less than $\chi^{2}$ table, so the conclusion is that the variances of the population are the same or homogeneous.

Table 3. Results for the normality test

\begin{tabular}{cccc}
\hline Normality test & $\mathrm{L}_{\text {observation }}$ & $\mathrm{L}_{\text {table }}$ & Decision \\
\hline POGIL learning model & 0.04577 & 0.09499 & Ho is not rejected \\
Direct learning model & 0.08640 & 0.09237 & Ho is not rejected \\
High self-regulated learning & 0.05768 & 0.13208 & Ho is not rejected \\
Medium self-regulated learning & 0.08480 & 0.11252 & Ho is not rejected \\
Low self-regulated learning & 0.12671 & 0.13063 & Ho is not rejected \\
\hline
\end{tabular}

Table 4. Results for the homogeneity test

\begin{tabular}{cccc}
\hline Homogeneity test & $\chi^{2}$ observation & $\chi^{2}$ table & Decision \\
\hline $\begin{array}{c}\text { POGIL learning model and } \\
\text { direct learning model }\end{array}$ & 0.84879 & 3.84100 & Ho is not rejected \\
$\begin{array}{c}\text { Self-regulated learning high, } \\
\text { medium and low }\end{array}$ & 2.04152 & 5.99100 & Ho is not rejected \\
\hline
\end{tabular}

\subsection{Two way ANOVA test with unbalanced cells}

Two way analysis of variances with unbalanced cells was carried out to test the significance of the effect of an independent variable on a dependent variable. Hypothesis testing looks at whether there is a difference in mathematical connection ability between each learning model and self-regulated learning, and the interaction of the two independent variables with mathematical connection ability.

Table 5 shows the conclusions of the two path variance analysis with unequal cells are (a) In A factor, $\mathrm{F}_{\text {obsevation }}=57.43386$ with $\mathrm{CR}=\{\mathrm{F} \mid \mathrm{F}>3.89577\}$. $\mathrm{F}_{\text {observation }} \in \mathrm{CR}$, so $\mathrm{H}_{\mathrm{oA}}$ is rejected. This result means that there are differences in mathematical connection ability to the learning model. (b) In $\mathrm{B}$ factor, $\mathrm{F}_{\text {obsevation }}=$ 12.35994 with $\mathrm{CR}=\{\mathrm{F} \mid \mathrm{F}>3.04821\} . \mathrm{F}_{\text {observation }} \in \mathrm{CR}$, so $\mathrm{H}_{\mathrm{oB}}$ is rejected. This result means that there are differences in mathematical connection ability to self-regulated learning. (c) In $\mathrm{AB}$ factor, $\mathrm{F}_{\text {obsevation }}=$ 1.77471 with $\mathrm{CR}=\{\mathrm{F} \mid \mathrm{F}>3.04821\}$. $\mathrm{F}_{\text {observation }} \notin \mathrm{CR}$, so $\mathrm{H}_{\mathrm{oB}}$ is not rejected. This result means that there is no interaction between the self-regulated learning model and mathematical connection ability. These circumstances, whether or not the learning model does not depend on students' self-regulated learning. 
Table 5. The results of two-way ANOVA test with unbalanced cells

\begin{tabular}{ccccccr}
\hline Source & $\mathrm{SS}$ & $\mathrm{df}$ & $\mathrm{MS}$ & $\mathrm{F}_{\text {observation }}$ & $\mathrm{F}_{\text {table }}$ & Decision \\
\hline Learning model (A) & 15576.43 & 1 & 15576.43 & 57.43386 & 3.89577 & $\mathrm{H}_{0 \mathrm{~A}}$ is rejected \\
Self-regulated learning (B) & 6704.19 & 2 & 3352.10 & 12.35994 & 3.04821 & $\mathrm{H}_{0 \mathrm{~B}}$ is rejected \\
Interaction (AB) & 962.63 & 2 & 481.31 & 1.77471 & 3.04821 & $\mathrm{H}_{0 \mathrm{AB}}$ is not rejected \\
Error (G) & 46918.72 & 173 & 271.21 & & & \\
Total & 70161.97 & 178 & & & & \\
\hline
\end{tabular}

The $\mathrm{H}_{\mathrm{oA}}$ test result rejected, meaning that in this case the learning model variable has only two values, so there is no need to make a post-ANOVA comparison between lines. Therefore, inference by looking at the marginal mean after POGIL learning model statistics and direct learning models differ mathematical connection ability. Besides, the $\mathrm{H}_{\mathrm{oB}}$ result rejected which means that there are three values for the self-regulated learning variable, so it is necessary to conduct further post hoc tests using the Scheffe method to see which categories of self-regulated learning provide different effects or multiple comparisons between columns. $\mathrm{H}_{\mathrm{AB}}$ result is not rejected, which means that there is no need to do further tests between cells in the same column or lines. This result implies that differences in the mathematical connection ability between students with high, medium, and low self-regulated learning in each learning model are the same as in general conclusions.

\subsection{Multiple comparisons}

Before making a paired comparison, the marginal mean and the average of each cell are searched first, the results of which shown in Table 6. Table 6 shows that the average marginal of POGIL learning model is 52.20, while the average marginal of direct learning model is 32.14 . This result means that the average POGIL learning model is better than the average direct learning model. During the activities using POGIL [16], students are completely off track in their reasoning process, but problems can be solved immediately by the instructor, either by providing small information or by asking questions probing further. In contrast, with the traditional class format, misunderstandings are rarely revealed, and they become deep-rooted and persistent misunderstandings outside the classroom. Assessment of students' understanding and misunderstanding also guides future teaching by enabling teachers to anticipate better why students experience difficulties with the linkage of certain concepts.

Table 6. Marginal average cells

\begin{tabular}{ccccc}
\hline \multirow{2}{*}{ Learning model (A) } & \multicolumn{3}{c}{ Self-regulated learning (B) } & Marginal \\
& High & Medium & Low & average \\
\hline POGIL learning model & 61.48 & 54.33 & 40.78 & 52.20 \\
Direct learning model & 39.17 & 29.62 & 27.64 & 32.14 \\
Marginal average & 50.32 & 41.97 & 34.21 & \\
\hline
\end{tabular}

Several studies by [17-19] that the POGIL model is better than the direct learning model. POGIL has been successfully applied to many programs, including biochemistry, physical chemistry, pharmaceuticals, and marketing [20-23]. In this research, POGIL aims to make students actively involved and think in the mathematics classroom. During the exploration phase, students presented with adequate information. This model will ensure the right foundation for building knowledge and understanding. Then, the questions arranged so that all students arrive at the correct conclusions and support the development of process skills. Students who have their respective roles in the group not only understand their learning, but the teacher or instructor also guides students in ways that still allow them to find their concepts.

Research from Brown [23] concludes that POGIL improves classroom outcomes for students, encourages active involvement with the material during class time, provides direct feedback to teachers about knowledge students have not mastered, and creates a class environment that is well received by students. Essential elements for POGIL implementation are the use of small groups of students with their roles (manager, recorder, presenter and reflector), the role of instructors as facilitators, the use of activities designed generally to follow the paradigm of the learning cycle, and the emphasis on developing process skills in addition to mastering content [24].

Table 7 shows the first hypothesis $\mu_{.1}=\mu_{.2}$, ie the first and second columns obtained $\mathrm{F}_{.1-2}=8.63433$ with $\mathrm{CR}=\{\mathrm{F} \mid \mathrm{F}>6.09642\}$, so $\mathrm{F}_{\text {observation }} \in \mathrm{CR}$, resulting in $\mathrm{H}_{\mathrm{o}}$ being rejected. This result means that there are differences in mathematical connection ability between students with high self-regulated learning and moderate self-regulated learning. Based on the marginal mean in Table 6 shows that the average value of students' mathematical connection ability with high self-regulated learning is 50.32 greater than the average 
value of students with medium self-regulated learning, which is 41.97 . Thus it can be concluded that students with high self-regulated learning provide better mathematical connection ability than students with moderate self-regulated learning.

Table 7. Inter-colomns comparison test results

\begin{tabular}{cccc}
\hline $\mathrm{H}_{0}$ & $\mathrm{~F}_{\text {observation }}$ & $\mathrm{F}_{\text {table }}$ & Decision \\
\hline$\mu_{.1}=\mu_{.2}$ & 8.63433 & 6.09642 & Ho is rejected \\
$\mu_{.1}=\mu_{.3}$ & 24.56065 & 6.09642 & Ho is rejected \\
$\mu_{.2}=\mu_{.3}$ & 7.45337 & 6.09642 & Ho is rejected \\
\hline
\end{tabular}

In the second hypothesis $\mu_{.1}=\mu_{.3}$, the first and second columns are obtained $F_{.1-.3}=24.56065$ with $\mathrm{CR}=\{\mathrm{F} \mid \mathrm{F}>6.09642\}$, so $\mathrm{F}_{\text {observation }} \in \mathrm{CR}$, resulting in Ho being rejected. This result means that there are differences in mathematical connection ability between students with high self-regulated learning and low self-regulated learning. Based on the marginal mean in Table 6 shows that the average value of students' mathematical connection ability with high self-regulated learning is 50.32 greater than the average value of students with medium self-regulated learning, which is 34.21. Thus it can be concluded that students with high self-regulated learning provide better mathematical connection ability than students with low self-regulated learning.

In the third hypothesis $\mu_{.2}=\mu_{.3}$, the first and second columns are obtained $\mathrm{F}_{.2-3}=7.45337$ with $\mathrm{CR}=$ $\{F \mid F>6.09642\}$, so $F_{\text {observation }} \in \mathrm{CR}$, resulting in Ho being rejected. This result means that there are differences in mathematical connection ability between students with moderate self-regulated learning and low self-regulated learning. Based on the marginal mean in Table 6 shows that the average value of students' mathematical connection ability with moderate self-regulated learning is 41.97 greater than the average value of students with low self-regulated learning, which is 34.21. Thus it can be concluded that students with self-regulated learning are providing better mathematical connection ability than students with low self-regulated learning.

Self-regulated learning emphasises the active role of students. They set goals to get good results in their learning, monitor progress towards their goals, and regulate cognition, motivation, and behaviour to achieve their goals [25]. Besides, various strategies are used to help students decide whether their learning process should proceed in the same way or if necessary some changes [26]. Research conducted by Yildizli [27] shows that self-regulated learning effectively supports learning. Students with high selfregulated learning tend to be more prepared when facing learning in class because they have prepared the material taught even students to have a variety of relevant sources to support their learning. However, low self-regulated learning students tend to ask a lot of help or direction from the teacher in solving problems before trying to solve them themselves. Students who can organize themselves academically are more successful than students with low self-regulated learning skills or those who do not have self-regulated learning in their learning [28]. As for students, they must try to increase their self-efficacy beliefs by regularly engaging in academic assignments [29, 30].

\section{CONCLUSION}

The POGIL model produces better mathematical connection skills than the direct learning model. Students with high category self-regulated learning have better mathematical connection ability than the medium and low categories, and students with medium category self-regulated learning produce have mathematical connection ability than the low category.

\section{REFERENCES}

[1] S. Heppel, et al., $21^{\text {st }}$ Century School: Learning Environments of The Future. London: CABE \& RIBA, 2004.

[2] Soedjadi R., Mathematics Education Tips in Indonesia (in Bahasa). Indonesia: Direktorat Jenderal Pendidikan Tinggi Departemen Pendidikan Nasional, 2000.

[3] NCTM, Principles and Standards for School Mathematics. United States of America: NCTM, 2000.

[4] Wei M. H. and Dzeng H. A., "Comparison Study of Math Education and Math Performance Between Asian Countries and The United States," Journal of Socialomics, vol. 3, no. 2, pp. 2167-0358, 2014.

[5] Guinocor M., et al., "Mathematics Performance of Students in a Philippine State University," International Electronic Journal of Mathematics Education.vol. 15, no. 3, pp. 1-14, 2020.

[6] Hendriana, Rohaeti, and Sumarmo, Hard Skill dan Soft Skill Matematik Siswa. Bandung: PT Refika Aditama, 2018.

[7] Sugiman, "Mathematical Connections in Mathematics Learning in Middle School (in Bahasa)," Jurnal Pendidikan Matematika Phythagoras, vol. 4, no. 1, pp. 56-66, 2008. 
[8] Yilmaz, A. and Sen, S., "The Effects of Process Oriented Guided Inquiry Learning Environment on Students' Self Regulated Learning Skills," Journal Problems of Education in the $21^{\text {st }}$ Century, vol. 66, no. 1, pp. 54-64, 2015.

[9] Straumanis, A., Classroom Implementation of Process Oriented Guided. Inquiry Learning, a Practical Guide for Instructor. USA: POGIL Org., 2010.

[10] Deni, F A, Masrukan, "The Analysis of Mathematical Literacy Skill and Respect to Local Culture toward Pogil Learning with Ethnomathematics," Unnes Journal of Mathematics Education Research, vol. 7, no. 2, pp. 145-151, 2018.

[11] Bransford, et al., How People Learn: Brain, Mind, Experience, and School. Washington: National Academy Press, 2000.

[12] Hanson, D M., Designing Process Oriented Guided Inquiry Activities. Lisle, IL: Pacific Crest, 2005.

[13] Hanson, D M., Instructor's Guide to Process Oriented Guided Inquiry Learning. Lisle, IL: Pacific Crest, 2006.

[14] Kanadli, S. and Ergen, B., "The Effect of Self Regulated Learning Strategies on Academic Achievement: A MetaAnalysis Study," Eurasian Journal of Education Research (EJER), vol. 69, no. 3, pp. 55-74, 2017.

[15] Zimmerman, "Becoming a Self Regulated Learner: An Overview," Theory into Practice Journal, vol. 41, no. 2, pp. 64-70, 2002.

[16] Geiger, M., "Implementing POGIL in Allied Halth Chemistry Courses: Insights from Process Education," International Journal of Process Education, vol. 2, no. 1, pp. 19-34, 2010.

[17] Irwanto, Saputro, A D, Roehati, E., and Prodjosantoso, A K., "Promoting Critical Thinking and Problem-Solving Skills of Preservice Elementary Teachers through Process-Oriented Guided-Inquiry Learning (POGIL)," International Journal of Instruction, vol. 11, no. 4, pp. 777-794, 2018.

[18] Zawadzki, R., "Is Process-Oriented Guided-Inquiry Learning (POGIL) Suitable as a Teaching Method in Thailand's Higher Education?” Asian Journal of Education and Learning, vol. 1, no. 2, pp. 66-74, 2010.

[19] Walker, L, Abdi-Rizak, Warfa, M., "Process Oriented Guided Inquiry Learning (POGIL) Marginally Affects Student Achievement Measures but Substantially Increases The Odds of Passing a Course," PloS ONE Journal, vol. 12, no. 10, pp. 1-17, 2017.

[20] Minderhout, V. and Loertcher, J., "Lecture-Free Biochemistry: A Process Oriented Guided Inquiry Approach," Biochem Mol Bio Educ., vol. 35, no. 3, pp. 172-180, 2007.

[21] Hinde, R J. and Kovac, J., "Student Active Learning Methods in Physical Chemistry," J Chem Educ., vol. 78, no. 1, pp. 93-99, 2001.

[22] Hale, D., and Mullen, L. G., "Designing Process-Oriented Guided-Inquiry Activities: A New Innovation for Marketing Class," Market Educ Rev.,vol. 19, pp. 73-80, 2009.

[23] Brown, S D., “A Process-Oriented Guided Inquiry Approach to Teachng Medicinal Chemistry,” Amecican Journal of Pharmaceutical Education, vol. 74, no. 7, pp. 1-6, 2010.

[24] Eberlein, T., et al., "Pedagogies of Engagement in Science: A Comparison of PBL, POGIL and PLTL," The International Journal of Biochemistry and Molecular Biology, vol. 38, no. 4, pp. 262-273, 2008.

[25] Pintrich, P R., "A Conceptual Framework for Assessing Student Motivation and Self-Regulated Learning in College Students," Educational Psychology Review, vol. 16, no. 4, pp. 385-407, 2004.

[26] Muis, K. R., "The Role of Epistemic Beliefs in Self-Regulated Learning," Educational Psychologist, vol. 42, no. 3, pp. 173-190, 2007.

[27] Yildizli, H and Saban, A., "The Effect of Self Regulated Learning on Sixth Grade Turkish Students' Mathematics Achievements and Motivational Beliefs," Journal Cogent Education, vol. 3, no. 1, pp. 1-17, 2016.

[28] Xiao, S, Yao, K., and Wang, T., "The Relationships of Self-Regulated Learning and Academic Achievement in University Students," Forum on Psychological Health education and counselling for School Students Conference, vol. 60, no. 4, pp. 1-4, 2019.

[29] Bakar, N A, Shuaibu, A., and Bakar, R A., "Correlation of Self-Regulated Learning and Academic Achievement among Universiti Sultan Zainal Abidin (UniSZA) Undergratuate Students," International Journal of Academic Research in Business and Social Sciences, vol. 7, no, 4, pp. 254-268, 2017.

[30] Leutwyler, B and Merki, K M., "School Effects on Students' Self-Regulated Learning," Journal of Educational Research, vol. 1, no. 1, pp. 197-223, 2009. 